\title{
THE EFFECT OF CHANGING SERUM OSMOLALITY ON THE RELEASE OF ANTIDIURETIC HORMONE IN CERTAIN PATIENTS WITH DECOMPENSATED CIRRHOSIS OF THE LIVER AND LOW SERUM OSMOLALITY
}

\author{
By LAURENCE E. EARLEY * AND CHARLES A. SANDERS $\dagger$ \\ (From the Thorndike Memorial Laboratory and the Second and Fourth [Harvard] Medical \\ Services, Boston City Hospital, and the Department of Medicine, Harvard \\ Medical School, Boston, Mass.)
}

(Submitted for publication October 15, 1958; accepted November 13, 1958)

Hyponatremia and lowered total solute concentration of the serum are commonly observed in patients with cirrhosis of the liver with ascites and edema $(1-4)$. The mechanisms responsible for this chronic depression of the osmolality of the body fluid are not clear. The normal person maintains the tonicity of his body fluid within narrow limits, and lowering this by the addition of sufficient water to the body promptly results in diminished secretion of antidiuretic hormone $(\mathrm{ADH})$ and the excretion of increased volumes of hypotonic urine until the osmolality of the serum returns to normal (5-7). In contrast, the patient with decompensated cirrhosis may excrete small volumes of hypertonic urine despite a much lower than normal serum osmolality (1-4). However, further lowering of the osmotic pressure in such a patient by the ingestion or infusion of water often leads to a diuretic response similar to that of the normal subject $(1,4)$.

It would thus appear that the patient with cirrhosis and with a hypotonic milieu who is able to vary urinary concentrations through wide ranges is either releasing $\mathrm{ADH}$ in response to a stimulus other than tonicity [such as changes in effective extracellular fluid volume $(2,3)]$, or that the responses to changes in osmotic pressure are regulated about a lower than normal tonicity. This study is concerned with patients with decompensated cirrhosis who maintain a low serum osmolality, and only those who are able to achieve a diuresis in response to hydration. It was the purpose to determine if, while such pa-

\footnotetext{
* Present address: Medical Service, Veterans Administration Hospital, Boston, Mass.

† Present address: Medical Service, Massachusetts General Hospital, Boston, Mass.
}

tients were undergoing a water diuresis, returning the serum osmolality to its original low level would result in the release of $\mathrm{ADH}$, as reflected by alterations in the flow and concentration of the urine.

\section{METHODS}

Subjects selected for study were patients with decompensated cirrhosis associated with the prolonged and excessive intake of alcoholic beverage. All had tense ascites with or without peripheral edema, mild to moderate elevations of serum bilirubin, and a persistently depressed serum osmolality. 1 All were free of cardiovascular and renal disease, and all had previously demonstrated the ability to produce a concentrated as well as a dilute urine. Only subjects able to achieve a flow of urine greater than $6 \mathrm{ml}$. per minute during the water load were studied. The group consisted of five male and two female patients.

Each study was begun in the morning at least one hour after a light breakfast, and where possible the study was carried out in a private room. Smoking was prohibited after the preceding evening, and the subjects remained recumbent throughout the procedure. All samples of urine were collected through an indwelling urethral catheter which was inserted on the morning of the study. Infusions were delivered through a needle inserted into a forearm vein or through a polyethylene catheter inserted into an antecubital vein. Samples of blood were collected through an indwelling Cournand needle inserted into a forearm vein of the opposite arm. To minimize the influence of emotional reactions on the results of the study the catheterization and venipunctures were performed at least 45 minutes prior to beginning the study. After an initial collection of urine and blood, each subject received a water load as an infusion of 4 per cent hexose (either invert sugar or fructose) solution alone, or in combination with tap water by mouth. The total gain of water was individualized in each subject so that high rates of urinary flow were achieved and

1 Determinations of the osmolality of the serum of 16 healthy adults ranged from 281 to $294 \mathrm{mOsm}$. The range of osmolalities of the sera of subjects chosen for study was 266 to $272 \mathrm{mOsm}$. 
maintained. Fifteen hundred $\mathrm{ml}$. was given during the first hour, and thereafter the infusion was regulated to deliver water in amounts equal to the flow of urine plus an additional $50 \mathrm{ml}$. per hour for insensible losses. When rates of urinary flow greater than $6 \mathrm{ml}$. per minute had been reached and maintained for a period of 45 to 60 minutes the infusion was changed to either 3 per cent or 5 per cent sodium chloride. The total amount of sodium chloride given was calculated to correct but not exceed the dilution effect of the water load. This was given rapidly over a period of 15 to 30 minutes. The infusion was then continued as 4 per cent hexose solution at a rate equal to the rates of urinary flow and estimated insensible losses. The positive balance of water was not allowed to fall below that which existed at the time of the maximal water diuresis.

Samples of blood were collected during the period of dilution and maximal urinary flow, midway through the infusion of hypertonic sodium chloride, and during the periods of diminishing urinary flow. The total volume of blood withdrawn prior to the infusion of saline was not in excess of $60 \mathrm{ml}$. in any subject. Samples of urine were collected at intervals of 10 to 20 minutes, the shorter intervals being necessary to avoid distention of the bladder during high rates of urinary flow. Bladder rinsing was not employed. All samples of serum and urine were frozen immediately.

Total solute concentrations in serum and urine were determined by freezing point depression using a Fiske osmometer. Concentrations of sodium were determined with an internal standard flame photometer. Creatinine concentrations in serum and urine were determined by the method of Hare (8). Calculations of the endogenous clearance of creatinine and the rate of sodium excretion were determined from periods when the flow of urine and the excretion of total solutes were stable in order to minimize the effect of urinary tract dead space and delay time.

TABLE I

Data pertaining to three subjects who experienced discomfort during the infusion of hypertonic $\mathrm{NaCl}$

\begin{tabular}{|c|c|c|c|c|c|}
\hline Subject & $\begin{array}{c}\text { Elapsed } \\
\text { time }\end{array}$ & $\begin{array}{l}\text { Urine } \\
\text { flow }\end{array}$ & $\begin{array}{l}\text { Urine } \\
\text { conc. }\end{array}$ & $\begin{array}{l}\text { Serum } \\
\text { conc. }\end{array}$ & Infusion \\
\hline \multirow[t]{3}{*}{ A } & $\begin{array}{c}\min . \\
-30-0 \\
0-15 \\
15-30 \\
30-45 \\
45-60\end{array}$ & $\begin{array}{c}\text { ml./min. } \\
0.7 \\
5.9 \\
7.3 \\
14.0 \\
12.5\end{array}$ & $\begin{array}{c}\text { mOsm./L. } \\
259 \\
126 \\
84 \\
57 \\
55\end{array}$ & $\begin{array}{c}\text { mOsm./L. } \\
269 \\
272 \\
261\end{array}$ & $\begin{array}{l}800 \mathrm{ml} \text {. water P.O. and } 1,250 \mathrm{ml} . \\
4 \% \text { invert sugar I.V. }\end{array}$ \\
\hline & $\begin{array}{l}60-75 \\
75-90\end{array}$ & $\begin{array}{r}11.5 \\
7.1\end{array}$ & $\begin{array}{l}58 \\
52\end{array}$ & 268 & $230 \mathrm{ml} .5 \% \mathrm{NaCl}$ \\
\hline & $\begin{array}{r}90-105 \\
105-120\end{array}$ & $\begin{array}{l}0.6 \\
0.8\end{array}$ & $\begin{array}{l}262 \\
323\end{array}$ & $\begin{array}{l}274 \\
272\end{array}$ & $75 \mathrm{ml} .4 \%$ invert sugar \\
\hline \multirow[t]{3}{*}{ B } & $\begin{array}{c}-30-0 \\
0-30 \\
30-45 \\
45-60 \\
60-75 \\
75-90 \\
90-105\end{array}$ & $\begin{array}{l}0.7 \\
4.3 \\
5.3 \\
5.8 \\
5.8 \\
6.3 \\
6.4\end{array}$ & $\begin{array}{r}347 \\
82 \\
78 \\
69 \\
50 \\
44 \\
40\end{array}$ & $\begin{array}{l}270 \\
258 \\
255 \\
253\end{array}$ & $\begin{array}{l}760 \mathrm{ml} \text {. water P.O. and } 1,450 \mathrm{ml} \text {. } \\
4 \% \text { invert sugar I.V. }\end{array}$ \\
\hline & $\begin{array}{l}105-120 \\
120-135\end{array}$ & $\begin{array}{l}8.7 \\
3.0\end{array}$ & $\begin{array}{l}30 \\
53\end{array}$ & $\begin{array}{l}271 \\
274\end{array}$ & $370 \mathrm{ml} .5 \% \mathrm{NaCl}$ \\
\hline & $\begin{array}{l}135-150 \\
150-165\end{array}$ & $\begin{array}{l}0.5 \\
0.5\end{array}$ & $\begin{array}{l}320 \\
453\end{array}$ & $\begin{array}{l}271 \\
268\end{array}$ & $50 \mathrm{ml} .4 \%$ invert sugar \\
\hline \multirow[t]{3}{*}{$C^{*}$} & $\begin{array}{r}0-15 \\
15-30 \\
30-45 \\
45-60\end{array}$ & $\begin{array}{l}2.7 \\
3.6 \\
5.4 \\
7.5\end{array}$ & $\begin{array}{l}305 \\
294 \\
238 \\
168\end{array}$ & $\begin{array}{l}266 \\
253\end{array}$ & $\begin{array}{l}600 \mathrm{ml} \text {. water P.O. and } 1,500 \mathrm{ml} \text {. } \\
4 \% \text { fructose I.V. }\end{array}$ \\
\hline & $60-75$ & 6.3 & 157 & & $380 \mathrm{ml} .5 \% \mathrm{NaCl}$ \\
\hline & $\begin{array}{l}75-90 \\
90-105\end{array}$ & $\begin{array}{l}2.0 \\
2.5\end{array}$ & $\begin{array}{l}332 \\
360\end{array}$ & 262 & $150 \mathrm{ml} .4 \%$ fructose \\
\hline
\end{tabular}

* Subject $\mathrm{C}$ received the water load as an infusion of 4 per cent fructose solution, and the samples of urine during the period of dilution gave a 4-plus reaction with Clinitest. The presence of fructose in these samples probably would have prevented minimal dilution even in the absence of ADH. All other subjects received 4 per cent invert sugar solution, and reducing substance was not detected in other urine samples. 


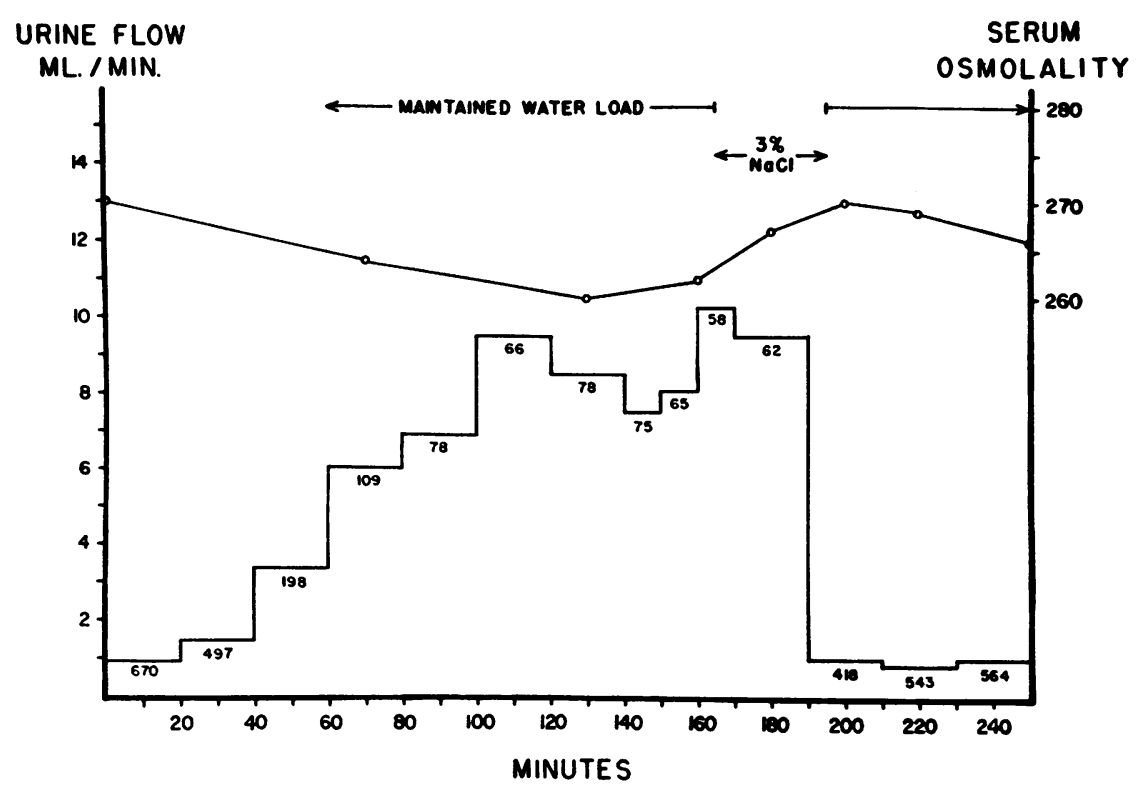

Fig. 1. Water Diuresis Followed by Antidiuresis When Serum Osmolality is Returned to the Initial Low LeVel (Subject F)

The line graph at the top represents osmolality of the serum. The bars below represent rates of urine flow. Figures superimposed on the bars denote osmolalities of the respective urine samples. The positive balance of water was maintained constant after the first hour as shown, and the period of infusion of hypertonic saline is indicated.

\section{RESULTS}

One subject was eliminated from the results of the study because of a spontaneous antidiuresis which occurred in association with observed emotional stress. Of the remaining six subjects, three experienced mild discomfort at the site of the infusion of hypertonic sodium chloride, and it cannot be concluded with certainty that the observed response was due to a change in tonicity and not to the distress associated with the infusion (9). Data pertaining to these subjects are summarized in Table I. The subjects who recived the infusions through venous catheters did not perceive the change from 4 per cent invert sugar solution to hypertonic sodium chloride, and no stimulus other than the changing tonicity was apparent. The data pertaining to these subjects are given in detail in Table II. Figure 1 graphically represents a typical subject from this latter group. The results are qualitatively the same in each of the six studies.

Lowering the osmolality of the serum 7 to 17 mOsm. as a result of dilution by the water load was associated with a rise in the rate of urinary flow and a fall in the osmolality of the urine in all six subjects. The peak rates of urinary flow ranged from 6.4 to $14.0 \mathrm{ml}$. per minute, and the minimal total solute concentrations ranged from 30 to $58 \mathrm{mOsm}$. (except Subject $\mathrm{C}$ who had hexosuria during the diluting phase and who had a minimal urinary concentration of $168 \mathrm{mOsm}$ ). Restoration of the osmolality of the serum to the pre-experimental levels by the hypertonic infusion was followed by a prompt decrease in the rate of urinary flow and rise in urinary concentration. In each subject small volumes of concentrated urine were produced during the first collection period following the infusion of sodium chloride. Maximal urinary total solute concentrations during the antidiuresis ranged from 323 to $544 \mathrm{mOsm}$. In each instance the hypertonic $\mathrm{NaCl}$ returned the total solute concentration of the serum to within $3 \mathrm{mOsm}$. of the initial level. During the study of Subject $B$ the osmolality of the serum exceeded the initial level by $4 \mathrm{mOsm}$. during the infusion of hypertonic saline, but in no subject did the con- 
TABLE II

Data pertaining to three subjects who attained water diuresis followed by antidiuresis without discomfort

\begin{tabular}{|c|c|c|c|c|c|c|c|c|c|}
\hline \multirow[b]{2}{*}{ Subject } & \multirow[b]{2}{*}{$\begin{array}{c}\text { Elapsed } \\
\text { time }\end{array}$} & \multirow[b]{2}{*}{$\begin{array}{l}\text { Urine } \\
\text { flow }\end{array}$} & \multirow[b]{2}{*}{$\begin{array}{l}\text { Urine } \\
\text { conc. }\end{array}$} & \multirow[b]{2}{*}{$\begin{array}{l}\text { Serum } \\
\text { conc. }\end{array}$} & \multirow[b]{2}{*}{$\begin{array}{l}\text { Serum } \\
\text { sodium }\end{array}$} & \multicolumn{2}{|c|}{$\begin{array}{l}\text { Renal excretion } \\
\text { rate of }\end{array}$} & \multirow[b]{2}{*}{$\begin{array}{c}\text { Clearance } \\
\text { of creatinine }\end{array}$} & \multirow[b]{2}{*}{ Infusion } \\
\hline & & & & & & $\begin{array}{l}\text { Total } \\
\text { solute }\end{array}$ & Sodium & & \\
\hline \multirow{4}{*}{$\mathrm{D}$} & $\min$ & $\operatorname{ml} . / \min$ & mOsm./L. & $m O s m . / L$ & $m E q . / L$ & $\underset{\min .}{\mu O O_{s m . l}}$ & $\underset{\min .}{\mu E q . /}$ & ml. $/ \min$. & \\
\hline & $\begin{array}{c}-30-0 \\
0-15 \\
15-30 \\
30-45 \\
45-60 \\
60-75 \\
75-90 \\
90-105\end{array}$ & $\begin{array}{r}0.6 \\
0.7 \\
0.6 \\
1.0 \\
3.8 \\
11.5 \\
13.2 \\
11.7\end{array}$ & $\begin{array}{r}\mathbf{5 4 3} \\
599 \\
576 \\
368 \\
130 \\
66 \\
52 \\
57\end{array}$ & $\begin{array}{l}262 \\
261\end{array}$ & 123 & $\begin{array}{l}326 \\
419 \\
346 \\
368 \\
494 \\
759 \\
689 \\
667\end{array}$ & 30.4 & 128 & $\begin{array}{l}950 \mathrm{ml} \text {. water P.O. } \\
\text { and } 1,450 \mathrm{ml} .4 \% \\
\text { invert sugar I.V. }\end{array}$ \\
\hline & $\begin{array}{l}105-120 \\
120-135\end{array}$ & $\begin{array}{l}8.3 \\
1.5\end{array}$ & $\begin{array}{r}72 \\
384\end{array}$ & $\begin{array}{l}260 \\
270\end{array}$ & & $\begin{array}{l}598 \\
576\end{array}$ & & & $360 \mathrm{ml} .5 \% \mathrm{NaCl}$ \\
\hline & $\begin{array}{l}135-150 \\
150-165\end{array}$ & $\begin{array}{l}1.3 \\
0.7\end{array}$ & $\begin{array}{l}544 \\
511\end{array}$ & $\begin{array}{l}271 \\
273\end{array}$ & 129 & $\begin{array}{l}707 \\
358\end{array}$ & 14.7 & 125 & $\begin{array}{l}75 \mathrm{ml} .4 \% \text { invert } \\
\text { sugar }\end{array}$ \\
\hline \multirow[t]{3}{*}{$\mathrm{E}$} & $\begin{array}{c}-35-0 \\
0-20 \\
20-40 \\
40-60 \\
60-80 \\
80-100 \\
100-125 \\
125-145\end{array}$ & $\begin{array}{l}0.9 \\
0.8 \\
1.5 \\
3.4 \\
5.4 \\
7.1 \\
9.0 \\
7.3\end{array}$ & $\begin{array}{r}437 \\
439 \\
335 \\
135 \\
86 \\
65 \\
49 \\
58\end{array}$ & $\begin{array}{l}264 \\
265\end{array}$ & 131 & $\begin{array}{l}393 \\
351 \\
503 \\
459 \\
465 \\
462 \\
441 \\
448\end{array}$ & 24.5 & 200 & $\begin{array}{l}2,600 \mathrm{ml} .4 \% \text { in- } \\
\text { vert sugar I.V. }\end{array}$ \\
\hline & $\begin{array}{l}145-165 \\
165-185\end{array}$ & $\begin{array}{l}3.0 \\
1.8\end{array}$ & $\begin{array}{r}98 \\
207\end{array}$ & $\begin{array}{l}263 \\
268\end{array}$ & 128 & $\begin{array}{l}294 \\
373\end{array}$ & & & $250 \mathrm{ml} .5 \% \mathrm{NaCl}$ \\
\hline & $\begin{array}{l}185-205 \\
205-225 \\
225-245 \\
245-270\end{array}$ & $\begin{array}{l}1.1 \\
1.3 \\
1.2 \\
1.6\end{array}$ & $\begin{array}{l}318 \\
314 \\
\\
354\end{array}$ & $\begin{array}{l}268 \\
271\end{array}$ & 131 & $\begin{array}{l}350 \\
408 \\
\\
566\end{array}$ & 79.3 & 201 & $\begin{array}{l}200 \mathrm{ml} . \\
\text { sugar }\end{array}$ \\
\hline \multirow[t]{3}{*}{$\mathbf{F}$} & $\begin{array}{c}-35-0 \\
0-20 \\
20-40 \\
40-60 \\
60-80 \\
80-100 \\
100-120 \\
120-140 \\
140-150 \\
150-160\end{array}$ & $\begin{array}{l}0.7 \\
0.9 \\
1.4 \\
3.3 \\
6.0 \\
6.9 \\
9.5 \\
8.5 \\
7.5 \\
8.2\end{array}$ & $\begin{array}{r}692 \\
670 \\
497 \\
198 \\
109 \\
78 \\
66 \\
78 \\
75 \\
65\end{array}$ & $\begin{array}{l}270 \\
264 \\
260 \\
262\end{array}$ & 128 & $\begin{array}{l}488 \\
570 \\
662 \\
644 \\
654 \\
538 \\
624 \\
643 \\
563 \\
533\end{array}$ & 1.6 & 161 & $\begin{array}{l}2,400 \mathrm{ml} .4 \% \text { in- } \\
\text { vert sugar I.V. }\end{array}$ \\
\hline & $\begin{array}{l}160-170 \\
170-190\end{array}$ & $\begin{array}{r}10.2 \\
9.6\end{array}$ & $\begin{array}{l}58 \\
62\end{array}$ & 267 & 132 & $\begin{array}{l}592 \\
595\end{array}$ & 7.1 & 145 & $520 \mathrm{ml} .3 \% \mathrm{NaCl}$ \\
\hline & $\begin{array}{l}190-210 \\
210-230 \\
230-250 \\
250-270\end{array}$ & $\begin{array}{l}1.0 \\
0.8 \\
1.0 \\
1.0\end{array}$ & $\begin{array}{l}418 \\
543 \\
564 \\
552\end{array}$ & $\begin{array}{l}270 \\
269 \\
\\
266\end{array}$ & 131 & $\begin{array}{l}418 \\
415 \\
564 \\
552\end{array}$ & 13.2 & 159 & $\begin{array}{l}150 \mathrm{ml} .4 \% \text { invert } \\
\text { sugar }\end{array}$ \\
\hline
\end{tabular}

centration reach the normal range of serum osmolality.

The endogenous clearance of creatinine was determined in three subjects. In one subject there was a small rise which persisted after hydration, in one there was a small rise during hydration and a return to the initial level during the antidiuresis, and in the third subject there was no significant change throughout the procedure. These values were all within normal limits.

\section{DISCUSSION}

The ability of the decompensated cirrhotic to excrete a standard intake of water has been quantitatively studied and reported elsewhere $(1,4)$. Many may achieve varying degrees of diuresis, 
but occasionally the decompensated cirrhotic may be unable to produce a urine more dilute than plasma $(2,3)$. The water loads given here were intended primarily to produce, where possible, an obvious water diuresis, and no conclusions can be made regarding the variation in diuretic responses. Only subjects who underwent a water diuresis were studied, and thus conclusions are applicable to this group only.

In normal subjects changes in effective osmotic pressure of the body fluids result in changes in the release of $\mathrm{ADH}$. Lowering the osmotic pressure by the gain of water results in an inhibition of the release of $\mathrm{ADH}$ and a loss of body water through the excretion of urine of lowered total solute concentration. Elevation of the osmotic pressure above normal by the loss of water or by the gain of effective solute (such as $\mathrm{NaCl}$ and other substances which do not readily cross the cell membrane) results in the release of $\mathrm{ADH}$ and the conservation of body water by the excretion of a concentrated urine. In this fashion the osmoreceptor-ADH system maintains the tonicity of the body fluids within narrow limits (5-7). Besides pharmacologic and psychic stimuli (10), another apparent mechanism concerned in the release of $\mathrm{ADH}$ appears to be related to changes in the extracellular fluid volume or some function thereof $(9,11-14)$.

The subjects reported here produced large volumes of dilute urine in association with lowering the osmotic pressure of the serum. Restoration of the original osmotic pressure, without a fall in total body volume, resulted in prompt antidiuresis. That these changes in urinary flow and concentration were probably due to changes in the release of $\mathrm{ADH}$ seems clear from the character of the urine. There were no marked variations in the rates of solute excretion, and it is unlikely that abrupt changes in the rates of glomerular filtration occurred. In the absence of such changes the observed differences in the flow and concentration of urine may be interpreted as the result of variations in the release of $\mathrm{ADH}(15,16)$. Without pharmacologic and psychic stimuli and with total body volume constant, these changes in the release of $\mathrm{ADH}$ seem clearly related to the changes in tonicity and its consequent effects. It may be concluded that at the time these subjects were studied they were sensitive to changes in osmotic pressure, and that the balance of water was regulated to maintain a fixed, although lower than normal, tonicity of the body fluids.

These studies shed no light on the mechanisms responsible in such subjects for a lowered tonicity of the body fluids. In other situations it has been observed that excessive ADH activity may result in the retention of water in excess of solute and thereby lead to hypotonicity $(17,18)$. It has been suggested that in cirrhosis of the liver decreased hepatic inactivation of the hormone may be a source of excessive antidiuretic activity (19-21), and likewise a decrease in effective extracellular fluid volume could be a stimulus for inappropriate release of the hormone. However, it would not appear that a constant high level of antidiuretic activity exists in subjects who are able to alter abruptly the rates of excretion of water such as those reported here and those of other reports where prompt responses to water loads were observed $(1,4)$. This subject has been critically reviewed recently by Papper (3).

Such a lowered setting of the osmoreceptor$\mathrm{ADH}$ system as demonstrated by the subjects reported here may possibly be related to a diminished amount of intracellular osmotic activity as has been suggested in other types of chronic hyponatremia (22). The results observed in this study are consistent with such a concept, but confirmation must await accurate volume determinations of the various fluid compartments in these and other states associated with altered osmotic pressure of the serum.

\section{SUMMARY}

The antidiuretic effect of hypertonic sodium chloride given during water diuresis was studied in six subjects with decompensated Laennec's cirrhosis and chronically depressed osmolality of the serum. It was found that marked antidiuresis ensued when the osmolality of the serum was restored to the initial low level without a change in the total volume of water in the body. It is concluded that these subjects with low serum sodium and total solute concentration were sensitive to further changes in tonicity, and that the release of antidiuretic hormone was regulated in a qualitatively normal fashion about a lower than normal level of osmolality. 


\section{ACKNOWLEDGMENTS}

The authors are gratefully indebted to Drs. Maurice B. Strauss and Solomon Papper for encouragement and suggestions during the course of these studies and preparation of this manuscript, and to Drs. Thomas C. Chalmers and C. Gardner Child, III, for the use of their laboratories.

\section{REFERENCES}

1. Birchard, W. H., Prout, T. E., Williams, T. F., and Rosenbaum, J. D. Diuretic responses to oral and intravenous water loads in patients with hepatic cirrhosis. J. Lab. clin. Med. 1956, 48, 26.

2. Strauss, M. B., Birchard, W. H., and Saxon, L. Correction of impaired water excretion in cirrhosis of the liver by alcohol ingestion or expansion of extracellular fluid volume: The role of the antidiuretic hormone. Trans. Ass. Amer. Phycns 1956, 69, 222.

3. Papper, S. The role of the kidney in Laennec's cirrhosis of the liver. Medicine (Baltimore). In press.

4. Papper, S., and Saxon, L. The diuretic response to administered water in patients with liver disease. II. Laennec's cirrhosis of the liver. Arch. intern. Med. In press.

5. Verney, E. B. Absorption and excretion of water: Antidiuretic hormone. Lancet 1946, 2, 781.

6. Verney, E. B. Antidiuretic hormone and the factors which determine its release. Proc. Roy. Soc. 1947, 135, 25.

7. Leaf, A., and Mamby, A. R. The normal antidiuretic mechanism in man and dog; its regulation by extracellular fluid tonicity. J. clin. Invest. 1952, 31, 54.

8. Hare, R. S. Endogenous creatinine in serum and urine. Proc. Soc. exp. Biol. (N. Y.) 1950, 74, 148.

9. Rydin, H., and Verney, E. B. The inhibition of water diuresis by emotional stress and by muscular exercise. Quart. J. exp. Physiol. 1938, 27, 343.

10. Strauss, M. B. Body Water in Man; the Acquisition and Maintenance of the Body Fluids. Boston, Little, Brown and Company, 1957.
11. Strauss, M. B., Davis, R. K., Rosenbaum, J. D., and Rossmeisl, E. C. "Water diuresis" produced during recumbency by the intravenous infusion of isotonic saline solution. J. clin. Invest. 1951, 30, 862.

12. Welt, L. G., and Orloff, J. The effects of an increase in plasma volume on the metabolism and excretion of water and electrolytes by normal subjects. J. clin. Invest. 1951, 30, 751.

13. Henry, J. P., Gauer, O. H., and Reeves, J. L. Evidence of the atrial location of receptors influencing urine flow. Circulat. Res. 1956, 4, 85.

14. Leaf, A., and Mamby, A. R. An antidiuretic mechanism not regulated by extracellular fluid tonicity. J. clin. Invest. 1952, 31, 60.

15. del Greco, F., and De Wardener, H. E. The effect on urine osmolarity of a transient reduction in glomerular filtration rate and solute output during a "water" diuresis. J. Physiol. (Lond.) 1956, $131,307$.

16. Berliner, R. W., and Davidson, D. G. Production of hypertonic urine in the absence of pituitary antidiuretic hormone. J. clin. Invest. 1957, 36, 1416.

17. Leaf, A., Bartter, F. C., Santos, R. F., and Wrong, O. Evidence in man that urinary electrolyte loss induced by pitressin is a function of water retention. J. clin. Invest. 1953, 32, 868.

18. Schwartz, W. B., Bennett, W., Curelop, S., and Bartter, F. C. A syndrome of renal sodium loss and hyponatremia probably resulting from inappropriate secretion of antidiuretic hormone. Amer. J. Med. 1957, 23, 529.

19. Ralli, E. P., Robson, J. S., Clarke, D., and Hoagland, C. L. Factors influencing ascites in patients with cirrhosis of the liver. J. clin. Invest. 1945, 24, 316.

20. Eversole, W. J., Birnie, J. H., and Gaunt, R. Inactivation of posterior pituitary antidiuretic hormone of the liver. J. clin. Endocr. 1948, 8, 616.

21. Hall, C. A., Frame, B., and Drill, V. A. Renal excretion of water and antidiuretic substances in patients with hepatic cirrhosis and rats with dietary liver injury. Endocrinology 1949, 44, 76.

22. Sims, E. A. H., Welt, L. G., Orloff, J., and Needham, J. W. Asymptomatic hyponatremia in pulmonary tuberculosis. J. clin. Invest. 1950, 29, 1545. 